\title{
Phytotoxicity evaluation of some dibrominated cinnamic acid derivatives on Phaseolus vulgaris
}

\author{
ALEXANDRA JITĂREANU ${ }^{1 *}$, CAMELIA IFRIM ${ }^{2}$, ANA-MARIA ZBANCIOC ${ }^{1}$, \\ ADRIANA TRIFAN ${ }^{1}$, URSULA STĂNESCU ${ }^{1}$, GABRIELA TĂTĂRÎNGĂ ${ }^{1}$
}

\author{
${ }^{1}$ University of Medicine and Pharmacy "Grigore T. Popa” Iaşi, Faculty of Pharmacy, Universitatii \\ street no 16, Iaşi, Romania \\ ${ }^{2}$ Botanical Garden “Anastasie Fătu” of "Alexandru Ioan Cuza“ University Iasi, Dumbrava Roşie \\ street no 7-9, 700487 Iaşi, România
}

\begin{abstract}
The phytotoxicity of eight dibrominated cinnamic acid derivatives on Phaseolus vulgaris was evaluated. Plant bioassays are usually used for ecotoxicity assessment and in the development of new pesticides, but they can also represent simple and inexpensive screening tools to identify well-tolerated substances before subjecting them to further more complex in vivo toxicity tests. Bean seeds were cultivated on filter paper impregnated with different concentrations of active substance $\left(28.6 \mu \mathrm{g} \mathrm{cm}^{-2}, 57.3 \mu \mathrm{g} \mathrm{cm}^{-2}, 114.6 \mu \mathrm{g} \mathrm{cm}^{-2}\right)$ and the development of the resulting seedlings was analyzed in comparison to a control group. Three aspects were observed: aspects of roots and seedlings growth, histo-anatomical changes induced in root tissues and alteration of polyphenols synthetic capacity. In most experimental cases, the exposure to the tested compounds inhibited the development of both roots and seedlings. In addition, some substances also caused histo-anatomical changes in the root tissues of bean seedlings. According to the results of the spectrophotometric determination, the total polyphenols content decreased after treatment for all the tested substances in comparison to the control, the reduction being directly proportional to the concentration of active substance. In conclusion, the experimental data revealed a certain degree of phytotoxicity for the investigated chemicals.
\end{abstract}

Keywords Aromatic carboxylic acids, common bean, histo-anatomy, morphology, total polyphenols content.

To cite this article: JITĂREANU A, IFRIM C, ZBANCIOC AM, TRIFAN A, STĂNESCU U, TĂTĂRÎNGĂ G. Phytotoxicity evaluation of some dibrominated cinnamic acid derivatives on Phaseolus vulgaris. Rom Biotechnol Lett. 2019; 24(6): 10151021. DOI: $10.25083 / \mathrm{rbl} / 24.6 / 1015.1021$ 


\section{Introduction}

Cinnamic acids are a group of aromatic carboxylic acids that can be found naturally in the plant kingdom. In the last ten years, the interest of researchers on the cinnamic acid moiety has notably increased. Several reviews and studies focused on evaluating different medicinal applications of cinnamic-related molecules: anticancer, antituberculosis, antimalarial, antifungal, antimicrobial, antiatherogenic and antioxidant activities (J.D. GUZMAN [1]).

During our previous research, we synthesized some cinnamic acid derivatives and their dibrominated analogues and we evaluated their antimicrobial potential. As expected, the addition of bromine determined the increase of the antibacterial and antifungal activity (A. JITAREANU \& al [2], B. NARASIMHAN \& al [3]).

Taking into consideration the fact that toxicity assessment is of great importance for pharmaceutical substances, we considered necesary to subject the biologically active substances to a phytobiological screening, in order to evaluate their influence on living organisms. For this, we investigated the effects of some nonbrominated cinnamic acid derivatives on Phaseolus vulgaris, observing the inhibitory effect of the tested compounds (A. JITAREANU \& al [4]).

Although plant bioassays are usually used to assess the ecotoxicity of different soil and water contaminants (W-M. LEE \& al [5], R. AZMAT \& al [6], R. AZMAT \& al [7], Y-J. AN \& al [8], G. FISKESJO \& al [9]), they can also provide some useful information about the toxic potential of a pharmaceutical substance for living organisms
(G. FISKESJO \& al [9]). Therefore, these tests can represent a screening tool used to identify the well-tolerated substances that can be subjected to further in vivo tests on laboratory animals and, finally, to clinical trials on human subjects. Also, phytobiological tests can be used in the development of new herbicidal agents (H.P. SINGHA \& al [10]).

The purpose of this paper was to determine the phytotoxicity of some cinnamic acid dibrominated analogues and to observe whether bromination of the double bond in cinnamic acids' molecules enhances both the antimicrobial activity and the toxicity of the compounds. There are very few references regarding the effects of brominated organic compounds on plants (S. SPAEPEN \& al [11]).

\section{Materials and Methods}

\section{Chemicals}

8 dibrominated analogues of cinnamic acid derivatives were tested: [2,3-dibromo-3-phenylpropanoic acid (I); 2,3-dibromo-3-(4-methoxyphenyl) propanoic acid (I $\left.\mathbf{I}_{2}\right)$; 2,3-dibromo-3-(3,4-dimethoxyphenyl) propanoic acid ( $\mathbf{I}_{\mathbf{3}}$ ); 2,3-dibromo-3-p-tolylpropanoic acid ( $\left.\mathbf{I}_{4}\right)$; 2,3-dibromo-3(4-chlorophenyl) propanoic acid (I5); 2,3-dibromo-3-(3bromophenyl) propanoic acid (I6); 2,3-dibromo-3-(3bromo-4-hydroxy-5-methoxyphenyl) propanoic acid $\left(\mathbf{I}_{7}\right)$; 2,3-dibromo-3-(4-hydroxy-3-methoxyphenyl) propanoic acid (I8)]. The substances were obtained by bromination, using liquid bromine. The structures of the compounds (Figure 1) were confirmed by spectral data and quantitative elemental analysis (A. JITAREANU \& al [2]).<smiles>[R]c1cc(C(Br)C(Br)C(=O)O)cc([R6])c1[R]</smiles>

I1 $\mathrm{R}_{1}=-\mathrm{H} ; \mathrm{R}_{2}=-\mathrm{H} ; \mathrm{R}_{3}=-\mathrm{H}$

I2 $\mathrm{R}_{1}=-\mathrm{OCH}_{3} ; \mathrm{R}_{2}=-\mathrm{H} ; \mathrm{R}_{3}=-\mathrm{H}$

I3 $\mathrm{R}_{1}=-\mathrm{OCH}_{3} ; \mathrm{R}_{2}=-\mathrm{OCH}_{3} ; \mathrm{R}_{3}=-\mathrm{H}$

I4 $\mathrm{R}_{1}=-\mathrm{CH}_{3} ; \mathrm{R}_{2}=-\mathrm{H} ; \mathrm{R}_{3}=-\mathrm{H}$

I5 $\mathrm{R}_{1}=-\mathrm{Cl} ; \mathrm{R}_{2}=-\mathrm{H} ; \mathrm{R}_{3}=-\mathrm{H}$

I6 $\mathrm{R}_{1}=-\mathrm{H} ; \mathrm{R}_{2}=-\mathrm{Br} ; \mathrm{R}_{3}=-\mathrm{H}$

I7 $\mathrm{R}_{1}=-\mathrm{OH} ; \mathrm{R}_{2}=-\mathrm{OCH}_{3} ; \mathrm{R}_{3}=-\mathrm{Br}$

I8 $\mathrm{R}_{1}=-\mathrm{OH} ; \mathrm{R}_{2}=-\mathrm{OCH}_{3} ; \mathrm{R}_{3}=-\mathrm{H}$

Figure 1. Structures of the tested compounds 


\section{The Phaseolus toxicity test}

The experiments used Phaseolus vulgaris seeds obtained from an experimental plot located at the research farm of the University of Agriculture and Veterinary Medicine Iasi. The seeds were sterilized, left in water to imbibe and placed to germinate between simple filter paper sheets; only the seeds that had germinated were used in the test. The toxicity tests were conducted in Petri dishes. 40 bean seeds per dish were placed on an artificial substrate (Whatman ${ }^{\circledR}$ no.1 circles of filter paper), impregnated with different dilutions of the tested substances, following the procedure presented in our previous work (A. JITAREANU $\&$ al [4]). Three active concentrations were tested for each substance (concentration A - $28.6 \mu \mathrm{g} \mathrm{cm}^{-2}$; concentration B $57.3 \mu \mathrm{g} \mathrm{cm}^{-2}$; concentration $\left.\mathrm{C}-114.6 \mu \mathrm{g} \mathrm{cm}^{-2}\right)$. In the $7^{\text {th }}$ day, the seedlings were separated from the filter paper and their development was observed in comparison to a control group, represented by seedlings unexposed to chemical treatments. The analyzed aspects were: aspects of roots and seedlings growth, histo-anatomical changes induced in the meristematic tissue and changes of polyphenols content (A. JITAREANU \& al [4], M. ATAK $\&$ al [12]).

\subsection{Aspects of roots and seedlings growth}

The seedlings and roots were measured and the percentages of growth inhibition in comparison to the control were calculated using the formula:

$$
\begin{gathered}
\% \text { Inh }=(\text { Control-I }) \times 100 / \text { Control (for both seedlings } \\
\text { and roots })
\end{gathered}
$$

\subsection{Histo-anatomical study}

The histo-anatomical changes induced in the meristematic tissue of bean roots under the influence of the synthesized compounds were observed only for the seedlings exposed to the highest tested concentration $\left(114.6 \mu \mathrm{g} \mathrm{cm}^{-2}\right)$. The roots were preserved in alcohol 70\% and then transverse sections were manually performed using the botanic razor. The resulting sections were treated with Javel water, then colored with ruthenium red and analyzed in Optika light microscope (G. SERBANESCUJITARIU \& al [13], A. JITĂREANU \& al [14], C. TANASE \& al [15]). The photographs were performed by using a Canon A50 camera.

\subsection{Total polyphenols quantification}

Polyphenols were extracted from $2 \mathrm{~g}$ of fresh vegetal material (shoots) using methanol $(50 \mathrm{~mL})$, under reflux conditions. The determination of total polyphenols was done using the Folin-Ciocalteu spectrophotometric method and gallic acid for the calibration curve (A. JITĂREANU $\&$ al [4]. C. ANESINI \& al [16]).

\section{Statistical analysis}

The experimental data were processed using the analysis of variance (ANOVA) for 0.05 and 0.01 significance levels. All the experiments included three replicates per treatment.

\section{Results and Discussion}

\section{Aspects of roots and seedlings growth}

The results regarding the treatments' impact on seedlings growth are presented in Table 1 .

In most cases, the exposure to the investigated compounds was followed by a reduction in lenght for both seedlings and roots, the inhibition percentages varying between $13.40 \%$ and $80.69 \%$ for seedlings and between $-11.14 \%$ and $81.22 \%$ for roots. In terms of changes induced to the growth process, the lowest phytotoxic potential was exhibited by compound $I_{8}$ (2,3-dibromo-3-(4-hydroxy-3methoxyphenyl) propanoic acid), while the highest toxicity was recorded for $\mathrm{I}_{6}$ (2,3-dibromo-3-(3-bromophenyl) propanoic acid). Similar results were obtained in our previous study concerning the non-brominated derivatives: the ferulic acid presented a low phytotoxicity, while for the 3-bromo-cinnamic acid were registered the highest percentages of inhibition in both seedling length and root length. Comparing these results with those obtained for their non-brominated analogues (A. JITĂREANU \& al [4]), there was no indication of phytotoxicity increase associated with addition of bromine.

The exposure of the seedlings to dibrominated ferulic acid $\left(I_{8}\right)$ caused a slight stimulation in roots' growth. Data presented in other scientific papers usually indicate an inhibitory effect on plant growth in the presence of ferulic acid (W.D. DOS SANTOS \& al [19]), but there are studies that also showed that the exposure of plants to low concentrations of compounds with phenol groups (polyphenols) can have a positive effect on roots growth (C. TANASE $\&$ al [15]).

The phytotoxic effect of the chemicals was also assessed by analysing their impact on the development of bean seedlings. Seedling growth and development is a complex phenomenon, controlled by a multitude of factors (plant hormones, a variety of external or environmental stimuli) and there is evidence that trans-cinnamic acid inhibits the activity of auxins and has long been considered an antiauxin, exhibiting an inhibitory effect on plant growth (L.M. SRIVASTAVA \& al [17], F.P. GARDNER $\&$ al [18]). 
Table 1. Effect of cinnamic acid dibrominated analogues on percentage of bean seedlings obtained, seedling length and root lenght

\begin{tabular}{|c|c|c|c|c|c|}
\hline $\begin{array}{c}\text { Compound / } \\
\text { Concentration }\end{array}$ & $\begin{array}{l}\text { Seedling lenght } \\
\quad \pm \mathrm{SD}(\mathrm{cm})\end{array}$ & $\begin{array}{c}\% \\
\text { Inh }\end{array}$ & $\begin{array}{l}\text { Root lenght } \pm \text { SD } \\
(\mathrm{cm})\end{array}$ & $\begin{array}{c}\% \\
\text { Inh }\end{array}$ & $\begin{array}{c}\text { Percentage of bean } \\
\text { seedlings obtained }(\%)\end{array}$ \\
\hline Control & $19.84 \pm 0.30$ & - & $11.40 \pm 0.29$ & - & 87.50 \\
\hline $\mathbf{I}_{1} / \mathbf{A}$ & $12.67 \pm 0.27 * *$ & 36.13 & $6.07 \pm 0.39 * *$ & 46.75 & 77.50 \\
\hline$I_{1} / \mathrm{B}$ & $12.06 \pm 0.40 * *$ & 39.21 & $5.50 \pm 0.42 * *$ & 51.75 & 70.00 \\
\hline $\mathbf{I}_{1} / \mathbf{C}$ & $11.56 \pm 0.25 * *$ & 41.73 & $5.53 \pm 017 * *$ & 51.49 & 47.50 \\
\hline $\mathbf{I}_{2} / \mathbf{A}$ & $13.96 \pm 0.13 * *$ & 29.63 & $7.26 \pm 0.17 * *$ & 36.31 & 72.50 \\
\hline $\mathbf{I}_{2} / \mathrm{B}$ & $12.68 \pm 0.11 * *$ & 36.08 & $6.29 \pm 0.27 * *$ & 44.82 & 62.50 \\
\hline$I_{2} / C$ & $11.55 \pm 0.25 * *$ & 41.78 & $6.81 \pm 0.23 * *$ & 40.26 & 47.50 \\
\hline $\mathbf{I}_{3} / \mathbf{A}$ & $13.76 \pm 0.22 * *$ & 30.64 & $8.12 \pm 0.26 * *$ & 28.77 & 75.00 \\
\hline$I_{3} / \mathrm{B}$ & $12.27 \pm 0.14 * *$ & 38.15 & $7.00 \pm 0.45 * *$ & 38.59 & 52.50 \\
\hline $\mathrm{I}_{3} / \mathrm{C}$ & $4.47 \pm 0.06^{* *}$ & 77.46 & $2.9 \pm 0.09 * *$ & 74.56 & 37.50 \\
\hline $\mathrm{I}_{4} / \mathrm{A}$ & $15.60 \pm 0.25 * *$ & 21.37 & $7.04 \pm 0.55^{* *}$ & 38.24 & 87.50 \\
\hline$I_{4} / \mathbf{B}$ & $13.86 \pm 0.14 * *$ & 30.14 & $6.62 \pm 0.38 * *$ & 41.92 & 85.00 \\
\hline $\mathrm{I}_{4} / \mathrm{C}$ & $10.46 \pm 0.18 * *$ & 47.27 & $6.11 \pm 0.19 * *$ & 46.40 & 55.00 \\
\hline$I_{5} / \mathrm{A}$ & $12.35 \pm 0.31 * *$ & 37.75 & $7.84 \pm 0.47 * *$ & 31.22 & 65.00 \\
\hline $\mathrm{I}_{5} / \mathrm{B}$ & $10.21 \pm 0.15 * *$ & 48.53 & $6.75 \pm 0.28 * *$ & 40.78 & 60.00 \\
\hline $\mathrm{I}_{5} / \mathrm{C}$ & $10.77 \pm 0.25 * *$ & 45.71 & $4.58 \pm 0.11 * *$ & 59.82 & 62.50 \\
\hline$I_{6} / \mathbf{A}$ & $12.23 \pm 0.18 * *$ & 38.35 & $4.62 \pm 0.31 * *$ & 59.47 & 67.50 \\
\hline $\mathrm{I}_{6} / \mathrm{B}$ & $10.42 \pm 0.21 * *$ & 47.47 & $3.28 \pm 0.26^{* *}$ & 71.22 & 47.50 \\
\hline$I_{6} / \mathrm{C}$ & $3.83 \pm 0.06^{* *}$ & 80.69 & $2.14 \pm 0.22 * *$ & 81.22 & 30.00 \\
\hline $\mathbf{I}_{7} / \mathbf{A}$ & $12.57 \pm 0.18 * *$ & 36.64 & $7.61 \pm 0.49 * *$ & 33.24 & 72.50 \\
\hline $\mathbf{I}_{7} / \mathbf{B}$ & $11.22 \pm 0.21 * *$ & 43.44 & $6.07 \pm 0.28 * *$ & 46.75 & 70.00 \\
\hline $\mathrm{I}_{7} / \mathrm{C}$ & $8.94 \pm 0.15^{* *}$ & 54.93 & $4.66 \pm 0.35^{* *}$ & 59.12 & 50.00 \\
\hline $\mathrm{I}_{8} / \mathrm{A}$ & $17.18 \pm 0.20 *$ & 13.40 & $12.91 \pm 0.83 \mathrm{~ns}$ & -13.24 & 87.50 \\
\hline $\mathrm{I}_{8} / \mathrm{B}$ & $16.43 \pm 0.22 *$ & 17.18 & $12.67 \pm 0.35 \mathrm{~ns}$ & -11.14 & 87.50 \\
\hline $\mathrm{I}_{8} / \mathrm{C}$ & $16.26 \pm 0.13^{*}$ & 18.04 & $12.81 \pm 0.65 \mathrm{~ns}$ & -12.36 & 62.50 \\
\hline
\end{tabular}

Legend: $\mathrm{A}=28.6 \mu \mathrm{g} \mathrm{cm}^{-2}, \mathrm{~B}=57.3 \mu \mathrm{g} \mathrm{cm}^{-2}, \mathrm{C}=114.6 \mu \mathrm{g} \mathrm{cm}^{-2} ; \mathrm{I}_{1}-\mathrm{I}_{8}$ correspond to the compounds presented in Figure 1 . Values are means \pm SD for three replicate in each group. Significant differences from control are marked with $*(p<0.05)$ or $* *(\mathrm{p}<0.01)$. ns means not significantly; \% Inh = percentage of growth inhibition in comparison to the control (for both seedlings and roots).

\section{Histo-anatomical study}

Another parameter investigated was the architecture of Phaseolus vulgaris roots. Some of the analyzed substances modified the histo-anatomy of the roots in the treated seedlings in comparison with the control.

The control plants' roots presented three regions: the rhizodermis, cortex and the stele. The rhizodermis presented numerous root hairs, specialized in absorbing nutrients. The cortex area was well developed a characteristic of young plants' roots. The central stellar region was relatively thick, with a tetrarch structure, presenting 4 poles of xylem, alternating with 4 poles of phloem. These results are according to those obtained by V. ZANOSCHI \& C. TOMA [20] and A.K.M.A. PRODHAN \& S.M.A. BARI [21].

The main differences that appeared in the transverse sections through the roots of the treated plants were associated with root hairs formation and changes induced in the structure of the vascular system (Figure 2).
Compound $\mathrm{I}_{7}$ (2,3-dibromo-3-(3-bromo-4-hydroxy-5methoxyphenyl) propanoic acid) stimulated the root hairs' growth (Figure 2B) in comparison with the chemically untreated seedlings (Figure 2A'). Similar results were also obtained by Tănase et al; the exposure of maize seedlings to small quantities of aqueous extract obtained from the spruce bark (rich in polyphenolic compounds) determined a good development of root hairs (C. TANASE \& al [15]). Meanwhile compound $I_{3}$ (2,3-dibromo-3-(3,4dimethoxyphenyl) propanoic acid) strongly inhibited the formation of root hairs (Figure 2C), affecting the absorption of water and nutrients, which ultimately led to growth reduction of the seedlings and changes in their morphology.

In the transverse sections on the meristematic region of seedlings exposed to compound $\mathrm{I}_{6}$ (2,3-dibromo-3-(3bromophenyl) propanoic acid) a major vascular anomaly was observed, as a marker of phytotoxicity, the tetrarch structure of the control was replaced by a pentarch one (Figure 2D). It is known that the internal anatomy of roots 
may be modified by environmental stress. Previous works showed that although roots of young cotton plants normally had tetrarch steles, when growing under nitrogen or phosphorus deficit they produced triarch or pentarch steles (H.A. MOONEY \& al [22]).

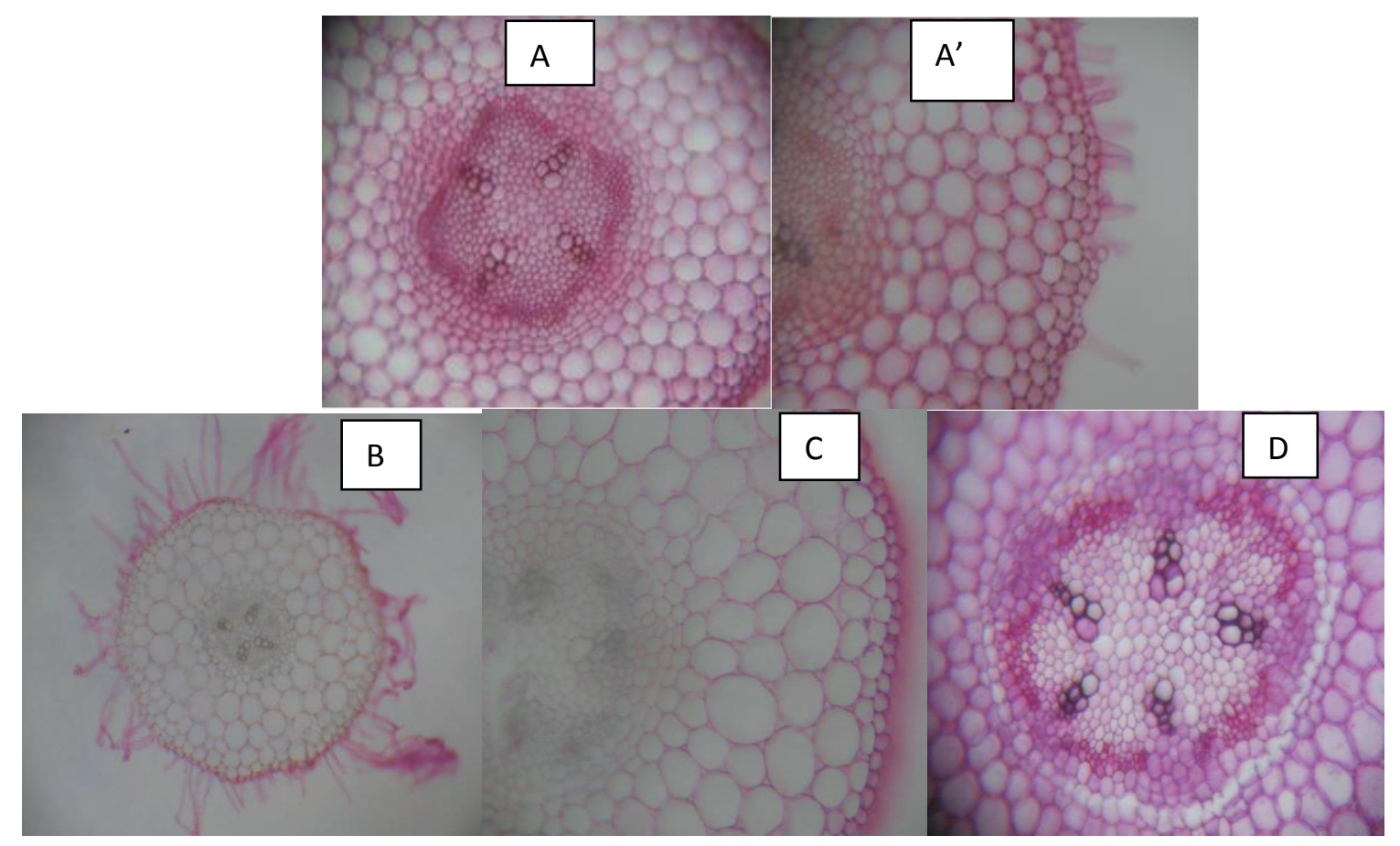

Figure 2. Histo-anatomical changes induced in the meristematic tissue by the tested compounds $\left(\mathrm{B}=\mathrm{I}_{7} ; \mathrm{C}=\mathrm{I}_{3} ; \mathrm{D}=\mathrm{I}_{6}\right)$ in comparison to the control group $\left(\mathrm{A}, \mathrm{A}^{\prime}=\right.$ control $)$ Magnification: x350 (B); x700 (A, A', C, D)

\section{Total polyphenols quantification}

According to the results of the spectrophotometric determination (Table 2), the content of total polyphenols in bean seedlings decreased after treatment for all the tested substances in comparison to the control, the reduction being directly proportional to the concentration of active substance. In two cases (compounds $\mathrm{I}_{3}$ and $\mathrm{I}_{6}$ ), at $114.6 \mu \mathrm{g} / \mathrm{cm}^{2}$, due to reduced mass of fresh seedlings obtained, the method used in the other cases could not be applied. Compound $\mathrm{I}_{6}$ (dibrominated 3-bromo-cinnamic acid), the one that exhibited the highest phytotoxic potential, also inhibited the biosynthesis of polyphenols. A significant reduction in total polyphenols content was also registered for compound $\mathrm{I}_{7}$ (dibrominated 5-bromo-ferulic acid).

Table 2. Total polyphenols content of the obtained bean seedlings, after treatment with cinnamic acid dibrominated derivatives $\mathrm{I}_{1}-\mathrm{I}_{8}$

\begin{tabular}{|c|c|c|c|}
\hline \multirow[t]{2}{*}{ Compound } & \multicolumn{3}{|c|}{$\begin{array}{c}\text { Concentration } \\
\text { (mg gallic acid equivalents GAE } 100 \mathrm{~g}^{-1} \text { ) }\end{array}$} \\
\hline & $28.6 \mu \mathrm{g} \mathrm{cm}^{-2}$ & $57.3 \mu \mathrm{g} \mathrm{cm}^{-2}$ & $114.6 \mu \mathrm{g} \mathrm{cm}^{-2}$ \\
\hline $\mathbf{I}_{1}$ & $75.13 \pm 0.92 * *$ & $71.05 \pm 0.46^{* *}$ & $61.87 \pm 0.89 * *$ \\
\hline $\mathbf{I}_{2}$ & $84.07 \pm 0.57 * *$ & $62.18 \pm 1.49 * *$ & $57.37 \pm 0.58 * *$ \\
\hline $\mathbf{I}_{3}$ & $86.94 \pm 1.25 \mathrm{~ns}$ & $52.22 \pm 0.36^{* *}$ & - \\
\hline $\mathbf{I}_{4}$ & $85.46 \pm 0.08^{*}$ & $78.41 \pm 0.88 * *$ & $59.19 \pm 1.08 * *$ \\
\hline $\mathbf{I}_{5}$ & $82.59 \pm 0.84 * *$ & $75.21 \pm 0.66 * *$ & $58.88 \pm 0.47 * *$ \\
\hline $\mathbf{I}_{6}$ & $77.66 \pm 1.24 * *$ & $55.65 \pm 0.34 * *$ & - \\
\hline $\mathbf{I}_{7}$ & $69.67 \pm 0.12 * *$ & $68.02 \pm 0.17 * *$ & $63.39 \pm 0.76^{* *}$ \\
\hline I8 & $85.34 \pm 0.49 *$ & $74.75 \pm 1.91 * *$ & $69.43 \pm 0.27 * *$ \\
\hline Control & \multicolumn{3}{|c|}{$87.94 \pm 0.22$} \\
\hline
\end{tabular}

Legend: $\mathrm{I}_{1}-\mathrm{I}_{8}$ correspond to the compounds presented in Fig. 1. Values are means \pm SD for three replicate in each group. Significant differences from controls are marked with $*(\mathrm{p}<0.05)$ or $* *(\mathrm{p}<0.01)$. ns means not significantly. 
The influence of polluants can lead to changes in plant metabolism, the most common being related to the accumulation of polyphenolic products. Polyphenols are a very important class of secondary metabolits in plants (O.T. OLARU \& al [23]). Polyphenols are produced by plants throughout their development for various reasons: the defense against microorganisms, insects and herbivores, availability of nutrients, exposure to ultraviolet radiation or due to allelopathic interactions. Studies showed that stress can influence the release of polyphenols from vacuoles as well as the synthesis of new phenols; these data can support the premise that these metabolites are major biomarkers that can be used to highlight the influence of pollutants and different chemical or physical factors (irradiation) on plants (M. KOALA \& al [24], B.G. BRASILEIRO \& al [25], R.H. ARMON \& O. HÄNNINEN [26], RAICIU D \& al [27], RAICIU D \& al [28]). Therefore, we decided to analyze the biochemical modifications that appeared in bean seedlings under the influence of the tested chemicals, because citoxicity is also surely associated with the alteration of metabolic processes (R. AZMAT \& al [7]).

\section{Conclusion}

In conclusion, the studied compounds exhibited a certain degree of phytotoxicity, inhibiting the development of Phaseolus vulgaris seedlings and the biosynthesis of polyphenols. The histo-anatomy of the roots in the treated seedlings was also modified and, in consequence, the toxic potential of the substances must be further investigated.

\section{References}

1. J. D. GUZMAN. Natural Cinnamic Acids, Synthetic Derivatives and Hybrids with Antimicrobial Activity. Molecules, 19: 19292-19349 (2014).

2. A. JITAREANU, G. TATARINGA, A-M. ZBANCIOC, C. TUCHILUS, U. STANESCU. Antimicrobial activity of some cinnamic acid derivatives. Rev. Med. Chir. Soc. Med. Nat. Iasi, 115 (3): 965-971 (2011).

3. B. NARASIMHAN, D. BELSARE, D. PHARANDE. Esters, amides and substituted derivatives of cinnamic acid: synthesis, antimicrobial activity and QSAR investigations. Eur. J. Med. Chem., 39 (10): 827-834 (2004).

4. A. JITAREANU, G. TATARINGA, A-M. ZBANCIOC, U. STANESCU. Toxicity of some cinnamic acid derivatives to common bean (Phaseolus vulgaris). Not. Bot. Horti. Agrobo., 39 (2): 130-134 (2011).
5. W-M. LEE, Y-J. AN, H. YOON, H-S. KWEON. Toxicity and bioavailability of copper nanoparticles to the terrestrial plants mung bean (Phaseolus radiatus) and wheat (Triticum aestivum): plant agar test for water-insoluble nanoparticles. Environ. Toxicol. Chem., 27 (9): 1915-1921 (2008).

6. R. AZMAT, S. HAIDER. Pb stress on phytochemistry of seedlings of Phaseolus mungo and Lens culinaris. Asian J. Plant Sci., 6 (2): 332-337 (2007).

7. R. AZMAT, S. HAIDER, S. ASKARI. Phytotoxicity of $\mathrm{Pb}$ : Effect of $\mathrm{Pb}$ on germination, growth, morphology and histomorphology of Phaseolus mungo and Lens culinaris. Pak. J. Biol. Sci., 9 (5): 979-984 (2006).

8. Y-J. AN. Assessment of comparative toxicities of lead and copper using plant assay. Chemosphere, 62: 1359-1365 (2006).

9. G. FISKESJO. The Allium test as a standard in environmental monitoring. Hereditas, 102: 99-112 (1985).

10. H.P. SINGHA, D.R. BATISH, S. KAURB, R.K. KOHLIA, K. ARORAB. Phytotoxicity of the volatile monoterpene citronellal against some weeds. Z. Naturforsch., C: J. Biosci., 61: 334-340 (2006).

11. S. SPAEPEN, J. VAN DURME, F. DAS, S. MAURER-STROH, F. ROUSSEAU, J. SCHYMKOWITZ, J. VANDERLEYDEN. Brominated phenols as auxin-like molecules. Eur. J. Soil Biol., 45: 81-87 (2009).

12. M. ATAK, K. MAVI, I. UREMIS. Bio-Herbicidal Effects of Oregano and Rosemary Essential Oils on Germination and Seedling Growth of Bread Wheat Cultivars and Weeds. Rom. Biotechnol Lett., 21 (1): 11149-11159 (2016).

13. G. SERBANESCU-JITARIU, M. ANDREI, N. RADUlECU-MITROIU, E. PETRIA. Practicum de biologie vegetala, Ceres, Bucuresti, 1983.

14. A. JITĂREANU, I. BOZ, G. TĂTĂRÎNGĂ, A-M. ZBANCIOC, U. STĂNESCU. The effects of some cinnamic acid derivatives on the architecture of Phaseolus vulgaris roots. Rom. Biotechnol Lett. 18 (3): 8317-8326 (2013).

15. C. TANASE, I. BOZ, V.I. POPA. Histo-Anatomic Aspects on Zea mays L. Influenced by Spruce Bark Polyphenolic Extract. Rom. Biotech Lett. 21 (1): 11238-11245 (2016)

16. C. ANESINI, G. FERRARO, R. FILIP. Total Polyphenol Content and Antioxidant Capacity of Commercially Available Tea (Camellia sinensis) in Argentina. J. Agric. Food Chem., 56: 9225-9229 (2008). 
17. L.M. SRIVASTAVA. Plant Growth and Development. Hormones and Environment. Academic Press, San Diego, 2002.

18. F.P. GARDNER, R.B. PEARCE, R.L. MITCHELL. Physiology of crop plants. Iowa State University Press, Ames, 1994.

19. W.D. DOS SANTOS, M.L.L. FERRARESE, O. FERRARESE-FILHO. Ferulic acid: an allelochemical troublemaker. Funct. Plant. Sci. Biotechnol., 2(1): 47-55 (2008).

20. V. ZANOSCHI, C. TOMA. Morfologia si anatomia plantelor cultivate, Ceres, Bucureti, 1985.

21. A.K.M.A. PRODHAN, S.M.A. BARI. Anatomy of lignosus bean (Dipogon lignosus) I: Root. Pakistan J. Biol. Sci., 4(9): 1052-1056 (2001).

22. H.A. MOONEY, W.E. WINNER, E.J. PELL. Response of Plants to Multiple Stresses. Academic press Inc, San Diego, 1991.

23. O.T. OLARU, G.M. NIŢULESCU, A. ORŢAN, N. BĂBEANU, O. POPA, D. IONESCU, C.E. DINUPÎRVU. Polyphenolic content and toxicity assessment of Anthriscus sylyestris Hoffm. Rom. Biotechnol Lett. 22 (6): 12054-12061 (2016).
24. M. KOALA, A. HEMA, K. SOMÉ, E. PALÉ, A. SÉRÉMÉ, J. BELEM, M. NACRO. Effects of Organic and Mineral Fertilizers on total Antioxidant, polyphenolic and carotenoid contents of Orange fleshed sweetpotato tubers. Journal of Natural Sciences Research (JNSR), 3 (6): 23-30 (2013).

25. B.G. BRASILEIRO, J.P.V. LEITE, V.W.D CASALI, V.R. PIZZIOLO, O.G.L. COELHO. The influence of planting and harvesting times on the total phenolic content and antioxidant activity of Talinum triangulare (Jacq.) Willd. Acta Sci., Agron., 37(2): 249-255 (2015).

26. R.H. ARMON, O. HÄNNINEN. Environmental Indicators, Springer Netherlands, Dordrecht, 2015.

27. D. RAICIU, O. LIVADARIU, C. MAXIMILIAN, A. BIRA. The evaluation of the effect of LED-s irradiation on wheat sprouts (Triticum aestivum L.). Rom. Biotechnol Lett., (2018). (https://www.rombio.eu/ docs/Raiciu\%20et\%20al.pdf) - in press.

28. A.D. RAICIU, O. LIVADARIU, C. MAXIMILIAN, A.M. CREȚU. The assesment of the effect induced by LED-s irradiation on garlic sprouts (Allium sativum L.). Rom. Biotechnol Lett., 23(6): 14187-14192 (2018) 